\title{
Influence of Parents, Peers and the Public on the Behavior of Street Children in Khartoum, Sudan
}

\author{
Sharifah Muhairah Shahabudin ${ }^{1}$, Najla Abdallah Mohammed ${ }^{1} \&$ Kuppusamy Singaravelloo $^{1}$ \\ ${ }^{1}$ Faculty of Business and Economics, University of Malaya, Kuala Lumpur, Malaysia \\ Correspondence: Sharifah Muhairah Shahabudin, University of Malaya, Kuala Lumpur, Malaysia. Tel: \\ 60-3-7967-3683. E-mail: muhairah@um.edu.my
}

Received: October 19, 2021

Accepted: December 3, $2021 \quad$ Online Published: December 13, 2021

doi:10.5430/rwe.v12n4p82

URL: https://doi.org/10.5430/rwe.v12n4p82

\begin{abstract}
Children living on the streets are a common sight in Khartoum, the capital city of Sudan, and other parts of the country. These children have been exposed to many types of pressure which influence behavior outcomes. This study aims to investigate the street children's socioeconomic profiles and examine the social-psychological influence of parents, peers and the public on the children's behavior. A systematic sampling technique was used to select 12 markets in Khartoum state. 350 street children from the 12 markets volunteered for the face-to-face interview administered questionnaire. The study found that parents stressors and peers stressors significantly influence the children to perform maladaptive behavior. However, the public did not have any significant effect on children's maladaptive behavior. The study suggests intervention programs should be applied to stop children from ending up on the streets by providing families with a basic income to guarantee children's welfare, security and sense of family life. To stop children from going back to the streets, a free education policy, fee waivers and free meals for poor children are recommended.
\end{abstract}

Keywords: street children, poverty, stressors, social psychology, risky behavior, deviant behavior

\section{Introduction}

\subsection{Introduce the Problem}

The issue of street children is a global social and humanitarian concern (Panter-Brick, 2002). Children who spend time being homeless are the most vulnerable to threats and deprivations. These children endure unstable and perilous lives that result in the deprivation of fundamental needs for safety, care, and supervision, and ultimately exposes them to exploitation and abuse of many forms (Mtonga, 2011). There is little assistance to help the most vulnerable children, forcing them to scavenge, beg, and sleep in the polluted slums of some of the poorest countries in the world (UNESCO, 2017). However, this issue has lingered, despite the advocacy and action by the public sector and NGOs.

The subject of street children is neither new nor it is limited to specific geographical areas or regions. North Sudan is one of the countries experiencing the problem that is rooted from a long-standing civil war resulting in impoverished families, displaced children, fragile economy and political instability (Belay, 2015; Poni-Gore, et al., 2015). These circumstances have forced many poor and displaced children to go to streets to earn their livelihood. This has caused a rise in the number of street children in Khartoum, the capital city of North Sudan (Assal, 2004; Hassan, Kobylarczyk, Kuśnierz-Krupa, Chałupski \& Krupa, 2017). Khartoum has also become a hub hosting refugees from neighbouring countries such as the Congo, Uganda, Chad, Eritrea and Ethiopia (Strachan, 2016; Marchand, Roosen, Reinold \& Siegel, 2017). Refugees in Khartoum are not located separately in camps but are amalgamated with the local community. Thus, it is very difficult to differentiate them as they share almost the same characteristics as the Sudanese children. According to the Sudanese Homeless Child Association, there are an estimated 700,000 street children in Khartoum, ranging from as young as 7 to 18 years old (Consortium for Street Children, 2004).

Most studies on street children in Sudan focuses largely on the factors that caused children to be on streets, their regular activities and coping startegies to survive the harsh street life (Plummer et al., 2007; Alshikh, 2010; Kudrati et al., 2008). However, little documented evidence exists showing street children's perceptions of parents and family, peers and the general public and the type of relationship they have with these groups of people. It is important to learn about their perceptions towards the family, peers and the public as it is learned that street children who do not 
have bonds with parents and family would develop a bond with "fictive family" on streets. The physical and emotional bond developed with the street family will eventually tie these children to the streets for a longer period, if not permanently (Belay, 2015). This is a cause for concern because the longer they stay on the streets, the more comfortable they are with the lifestyle, the more difficult it will be to include them in any development process that may improve their status and livelihood (Ahmad et. al., 2008). Hence, there is a need to build knowledge on the magnitude of the existing situation by assessing street children's perceptions towards their environment, which include their family, peers, and the public.

The Ecological Systems Theory (Bronfenbrenner, 1986, 1994), forms the overarching theoretical foundation of the study, emphasizing the interactions between individuals, in this case, street children, and the influences of their environment. This theory emphasizes various levels of interaction between individuals with their environment. At the first level, termed microsystems, is the interaction of a street child with people who have the strongest influence on his or her development, such as parents and siblings. In the case of Khartoum's street children, the push factor for a child's decision to be on the street is mainly economic hardship and poverty, relationship problems with stepparent and violence in the household (Kudrati, Plummer \& Yousif, 2008; Abdelmoneium, 2017; Endris \& Sitota, 2019). Ansell (2016) discovers that to escape from troubles at home, children moved to the streets and the aftermath of living on the streets intensifies their incompetence to ensure better livelihoods. The experience of living on low incomes or in poverty is almost always overwhelmingly negative, impacting children's self-esteem, causing feelings of powerlessness and isolation and restricted opportunities (Beresford, Green, Lister \& Woodard, 1999). Subsequently, there are also interactions between children and other parties, such as children's peers and the general public, which are related to a mesosystem. Peers play an important part in the children's daily lives as they are the source of information on how to survive street life. As a result, these children get involved in risky and deviant behaviors such as taking drugs, theft and sexual activities to relieve stress, to get respect from the group and to imitate the peers' habits because of peer's influence (Bah, 2018). Similarly, the street children are also exposed to risks when interacting with the public. There were cases of children who were sold to strangers and forced to beg on the streets and girls were targets of sexual assaults and exploitation (Bukoye, 2015). Moreover, the public views street children as uncontrollable, immoral, and unemotional beings and they have no sympathy towards the difficult situations that children face on the streets (Basnet, 2010).

Chamber (1983) argues that the type and the extent of deprivation experienced by individuals at any point in their life-course can have a detrimental effect on them which is often irreversible. There is evidence to suggest that the longer the duration of poverty, the more difficult it is for the afflicted person to escape from it. Yaqub (2002) emphasized that being poor for more than four years increased the probability of engaging in deviant behaviour to 90 percent. The current study looks at children who have experienced economic hardship and deprivation which led them into deviant behavior. If the children are not taken out of the poverty trap, such behavior may continue. Based on the arguments presented from the literature, this study aims to examine the social-psychological influence of parents, peers and the general public stressors on the children's behavior, given difficult living conditions, economic hardship and various forms of deprivations.

\section{Method}

\subsection{Sampling Procedure and Response Rate}

As a state, Khartoum is divided into seven localities: Khartoum, Jabal Awliya, Omdurman, Ombada, Karay, Bahri and Sharg El Nil. This study covers street children in three of these localities: Khartoum, Omdurman and Bahri. The sampling frame provided a list of 25 markets in the state, which was obtained from the General Administration for Social Welfare. The markets listed were rearranged in order of ascending size and numbered 1 to 25 . Based on a study by Azumah (2019), this study used a systematic sampling where only markets that have even-numbered codes were chosen. In total, after the sampling procedure, 12 markets were selected. Once done, the respondents within each market were approached to solicit voluntary participation. The investigators set an age criterion of respondents between 10 to 17 years old to elicit better response and understanding from the children. 350 working street children volunteered to participate in the survey. The researcher was assisted by two trained assistants who could speak the local dialect. The survey was conducted in Arabic and subsequently transcribed into English.

\subsection{Research Design}

A questionnaire was used as the key instrument for the study. The questions were adapted from (Wairimu, 2013). The questionnaire is developed into three sections: socio-demography, social psychological factors (parents, peers and general public stressors), maladaptive behavior. Data collection was conducted by the investigator with the help of two assistants from a non-profit organization who have dealt with street children in Khartoum. Face-to-face 
questionnaire administered interview was performed because majority of the street children were illiterate. For validation of the questionnaire, a pilot study was conducted on 30 street children in Khartoum.

\subsection{Ethics Approval}

The study obtained approval for the research to be performed on such children from University of Malaya Research Ethics Committee (UMREC) ref.no.UM.TNC2/RC/H\&E/UMREC-157. UMREC imposed that certain data of respondents such as their names, addresses, photos and contact numbers are prohibited. In addition, the National Council of Child Welfare, Ministry of Social Development and Child and Family Protection Unit in Sudan provided the approval to conduct the study at the site.

\section{Results}

\subsection{Demographic Profile of Respondents}

In total, 350 individuals completed the questionnaires, however, only the data from 330 questionnaires could be used for the analysis. Table 1 shows the demographic profiles of the respondents. The respondents were males and their ages ranged from 10 to 17 years. Many of the respondents (47.7\%) were aged 13-15 years old; and slightly more than half of the respondents have more than six siblings. For the birth order, $21.5 \%$ were the eldest child, $27.0 \%$ were second; and $20.3 \%$ were the third in the family.

Table 1. Profiles of street children and their parents $(\mathrm{n}=330)$ (Note 1)

\begin{tabular}{|c|c|c|c|}
\hline Variable & $(\%)$ & Variable & $(\%)$ \\
\hline Gender & & Age & \\
\hline Male & 92.4 & $10-12$ & 15.1 \\
\hline \multirow[t]{2}{*}{ Female } & 7.6 & $13-15$ & 47.7 \\
\hline & & $16-17$ & 37.2 \\
\hline No. of siblings & & Birth order among siblings & \\
\hline None & 1.2 & First & 21.5 \\
\hline $1-3$ & 12.4 & Second & 27.0 \\
\hline $4-5$ & 33.4 & Third & 20.3 \\
\hline $6-7$ & 31.3 & Fourth & 13.0 \\
\hline $8-22$ & 21.7 & Fifth and above & 18.2 \\
\hline Child's living arrangements & & About Schooling & \\
\hline Family (mother and father) & 50.9 & Proportion currently schooling & 29.7 \\
\hline Alone & 11.5 & Proportion lacking fees or school materials & 73.1 \\
\hline Single parent & 7.8 & & \\
\hline Relative $^{a}$ & 11.5 & & \\
\hline Siblings & 2.4 & & \\
\hline Guardians & 0.9 & & \\
\hline Friends & 14.8 & & \\
\hline Other $^{\mathrm{b}}$ & 0.2 & & \\
\hline Frequenting the streets & & Tenure on the streets & \\
\hline All day long & 79.1 & Less than a year & 50.3 \\
\hline During school holidays only & 15.5 & $1-4$ years & 30.6 \\
\hline Daily after school & 3.6 & More than 4 years & 19.1 \\
\hline Occasionally & 1.5 & & \\
\hline
\end{tabular}


Other ${ }^{\mathrm{c}}$

Child's main work

Shoe shiner

Collects metal scraps

Car washer

Begs

Random odd jobs

Contribution to family income

Most of the time

Sometimes

Rarely

Not at all
0.3

\section{Child's income per day}

13.9 Less than SP50

91.5

3.0 SP 51-100

5.2

13.9 SP 101-150

3.3

\section{People depend on your income}

47.9 No one $\quad 36.1$

7.9 Family 47.0

1.5 Single Parent 4.8

42.7 Siblings $\quad 5.5$

Data in Table 1 indicates that $70.3 \%$ of the respondents have dropped out of school. Close to three-quarters of the respondents $(73.3 \%)$ stated there was no one to pay for their school fees and other materials. Hence, it was important to identify with whom they stay, and the findings revealed that $50.9 \%$ stayed with family, $11.5 \%$ with relatives, and $14.8 \%$ stayed with friends. Only $11.5 \%$ lived on their own. Half the respondents $(50.3 \%)$ have been on the streets for less than one year, which means that this is the cohort of new entry into the streets. A further $30.6 \%$ have been there for up to 4 years and $19.1 \%$ have been on the streets for more than 4 years. Almost eight in ten (79.1\%) of the children were on the street the whole day, while the rest went on the streets during school holidays or after school hours, or occasionally.

Almost two-thirds of the respondents (65.9\%) performed various odd jobs such as being a waiter, waste disposer, cleaner, tea boy, a seller of mineral water, plastic bags, candy, fruits, vegetables and nuts. A further $13.9 \%$ of them worked as shoe shiners. Most of the respondents $91.5 \%$ earned less than SP 50 per day. It was also reported that $47.9 \%$ of the respondents contributed to the family income most of the time while $42.7 \%$ did not. The responses indicate that $36 \%$ of the respondents did not have persons who were dependent on their income, while $47.7 \%$ stated that their family depended on their income.

Table 2. Parents' education, occupation and family income $(\mathrm{n}=330)$ (Note 2)

\begin{tabular}{|c|c|c|c|}
\hline Background & & & \\
\hline & & Father & Mother \\
\hline Education & Illiterate & 43.6 & 53.3 \\
\hline & Primary/Intermediate $^{\mathrm{a}}$ & 32.7 & 29.2 \\
\hline & Quranic school & 13.4 & 10.3 \\
\hline & High school & 7.6 & 4.5 \\
\hline & Other & $2.7^{\mathrm{b}}$ & $2.7^{\mathrm{c}}$ \\
\hline Occupation & Unemployed & 19.4 & 10.3 \\
\hline & Casual work & 48.8 & 26.7 \\
\hline
\end{tabular}


Permanent job

Self-employed

Housewife

Other
10.3

18.5

$-$

$3.0^{\mathrm{d}}$

$3.7^{\mathrm{e}}$

1.2

9.1
SP Less than 500

SP 501-1500

SP $1501-3000$

$>$ SP 3000
49.0

Distribution (\%)

20.4

63.3

13.9

2.4

Table 2 shows parents' educational achievements and occupation(s) and family income. More mothers (53.3\%) were reported to be illiterate than fathers (43.6\%). In terms of education, $32.7 \%$ of fathers and $29.2 \%$ of mothers had only primary schooling. Those who had had religious education comprised $15.1 \%$ of fathers and $10.3 \%$ of mothers. In terms of occupation, $48.8 \%$ of fathers were casual workers while $19.4 \%$ were unemployed. Almost half the mothers (49\%) were housewives and $26.7 \%$ did casual work. The family income of the majority of respondents $(63.3 \%)$ fell between SP 501-1500, while 20.4\% made less than SP 500 and 13.9\% made SP1501 to 3000 a month.

\subsection{Adequacy of the Measurement Model}

Covariance-based Structural Equation Modelling using the AMOS (version 24) was conducted. It was applied first to validate the measurement model of social psychological factors and maladaptive behavior among working street children in Khartoum. Subsequently, the full-fledged structural model was conducted to examine the effect of the psychological factors (parents, peers and public stressors) influence on working street children's maladaptive behavior (risk behavior and deviant behavior).

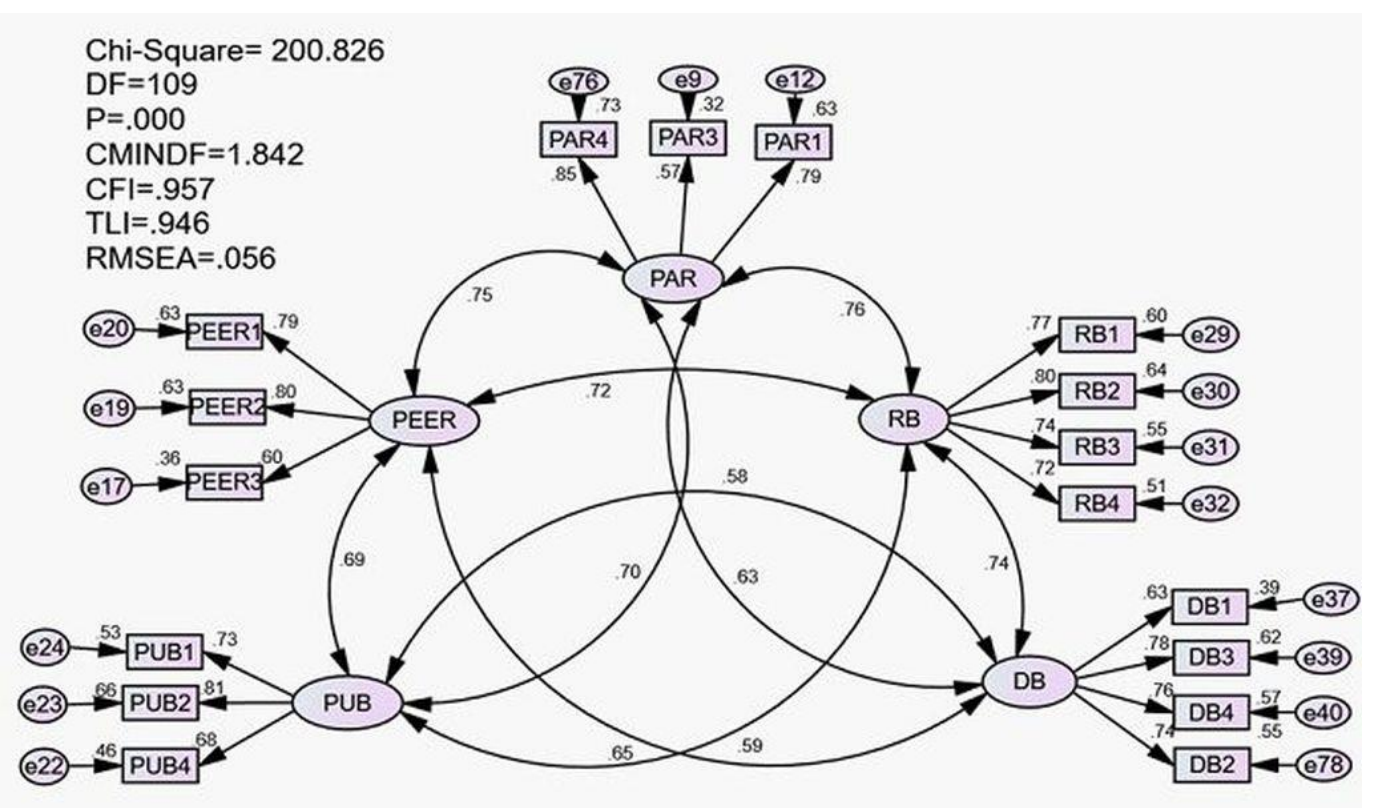

Figure 1. Confirmatory factor analysis results of Study Measurement Model 
Confirmatory Factor Analysis (CFA) conducted in the present study shows an acceptable fit with chi-square = 204.072, degrees of freedom $=109$; Normed chi-square $=1.842 ;$ RMSEA $=0.057$; Comparative Fit Indicator $(\mathrm{CFI})$ $=.956$; and Tucker-Lewis index $(\mathrm{TLI})=.946$. All these indices show the measurement model to be satisfactory.

\subsection{Measurement Model Reliability and Convergent Validity}

Table 3. Standardized factor loadings (Note 3)

\begin{tabular}{|c|c|c|c|c|c|c|c|}
\hline Factor & Items & $\begin{array}{l}\text { Factor } \\
\text { Loading }\end{array}$ & S.E. & T-value & P-value & AVE & CR \\
\hline \multirow{3}{*}{ Parents' influence } & PAR3 & .565 & NA & NA & NA & \multirow{3}{*}{0.557} & \multirow{3}{*}{0.786} \\
\hline & PAR1 & .792 & .166 & 9.049 & $* * *$ & & \\
\hline & PAR4 & .852 & .181 & 9.326 & $* * *$ & & \\
\hline \multirow{3}{*}{ Public influence } & PUB4 & .678 & .082 & 9.878 & $* * *$ & \multirow{3}{*}{0.539} & \multirow{3}{*}{0.776} \\
\hline & PUB2 & .814 & .083 & 11.247 & $* * *$ & & \\
\hline & PUB1 & .728 & NA & NA & NA & & \\
\hline \multirow{3}{*}{ Peer influence } & PEER3 & .599 & NA & NA & NA & \multirow{3}{*}{0.551} & \multirow{3}{*}{0.785} \\
\hline & PEER2 & .795 & .177 & 9.406 & $* * *$ & & \\
\hline & PEER1 & .792 & .144 & 9.387 & $* * *$ & & \\
\hline \multirow{4}{*}{ Risky Behaviour } & $\mathrm{RB} 1$ & .772 & NA & NA & NA & \multirow{4}{*}{0.574} & \multirow{4}{*}{0.843} \\
\hline & RB2 & .799 & .086 & 13.161 & $* * *$ & & \\
\hline & RB3 & .742 & .085 & 12.147 & $* * *$ & & \\
\hline & RB4 & .716 & .079 & 11.677 & $* * *$ & & \\
\hline \multirow{4}{*}{ Deviant Behaviour } & DB1 & .626 & NA & NA & NA & \multirow{4}{*}{0.533} & \multirow{4}{*}{0.819} \\
\hline & DB3 & .784 & .133 & 9.919 & $* * *$ & & \\
\hline & DB4 & .757 & .126 & 9.696 & $* * *$ & & \\
\hline & DB2 & .742 & .119 & 9.570 & $* * *$ & & \\
\hline
\end{tabular}

Table 3 shows that the values for the entire standardized factor loadings were above 0.50 , showing first evidence of convergent validity. Equally, t-value critical ratios were all outside the range of $-1.96 ; 1.96$ with the p-values less than 0.001 for every item measured. This result indicates there is statistical significance. In addition, the Average Variance Explained (AVE) values for each construct are equally presented in the Table. Each AVE factor is well above 0.50 . These outcomes reveal that there is strong evidence of convergent validity among the constructs of the psychological and maladaptive behavior factors measurement model. The factors are constructed after removing insignificant items. 


\subsection{Divergent Validity}

Table 4. Divergent validity test outcomes

\begin{tabular}{llllll}
\hline Constructs & Peers & Parents & Risk & Public & Deviant \\
\hline Peers & 0.734 & & & & \\
Parents & 0.568 & 0.747 & & & \\
Risk & 0.512 & 0.583 & 0.758 & & \\
Public & 0.470 & 0.485 & 0.352 & 0.742 & 0.730 \\
Deviant & 0.419 & 0.391 & 0.546 & 0.337 & \\
\hline
\end{tabular}

The Divergent Validity of the psychological and maladaptive behavior factors measurement model was estimated. The outcome is presented in Table 4. The correlation matrix, which shows inter-factor correlations, is located below the diagonal. The entire set of inter-factor correlations falls below 0.85 . This outcome provides strong and desirable evidence for discriminant validity for the psychological and maladaptive behavior factors measurement model.

\subsection{Adequacy of the Hypothesized Structural Model}

After checking the psychometric properties of the psychological and maladaptive behavior factors measurement model in terms of the convergent validity, discriminant validity and reliability, the structural model was conducted to examine the influence of the dimensions of the psychological factors (influence of parents, peers and the public) on-street working children's maladaptive behavior, which addressed the three hypothesized relationships of the model i.e. $\mathrm{H} 1, \mathrm{H} 2$ and $\mathrm{H} 3$ respectively.

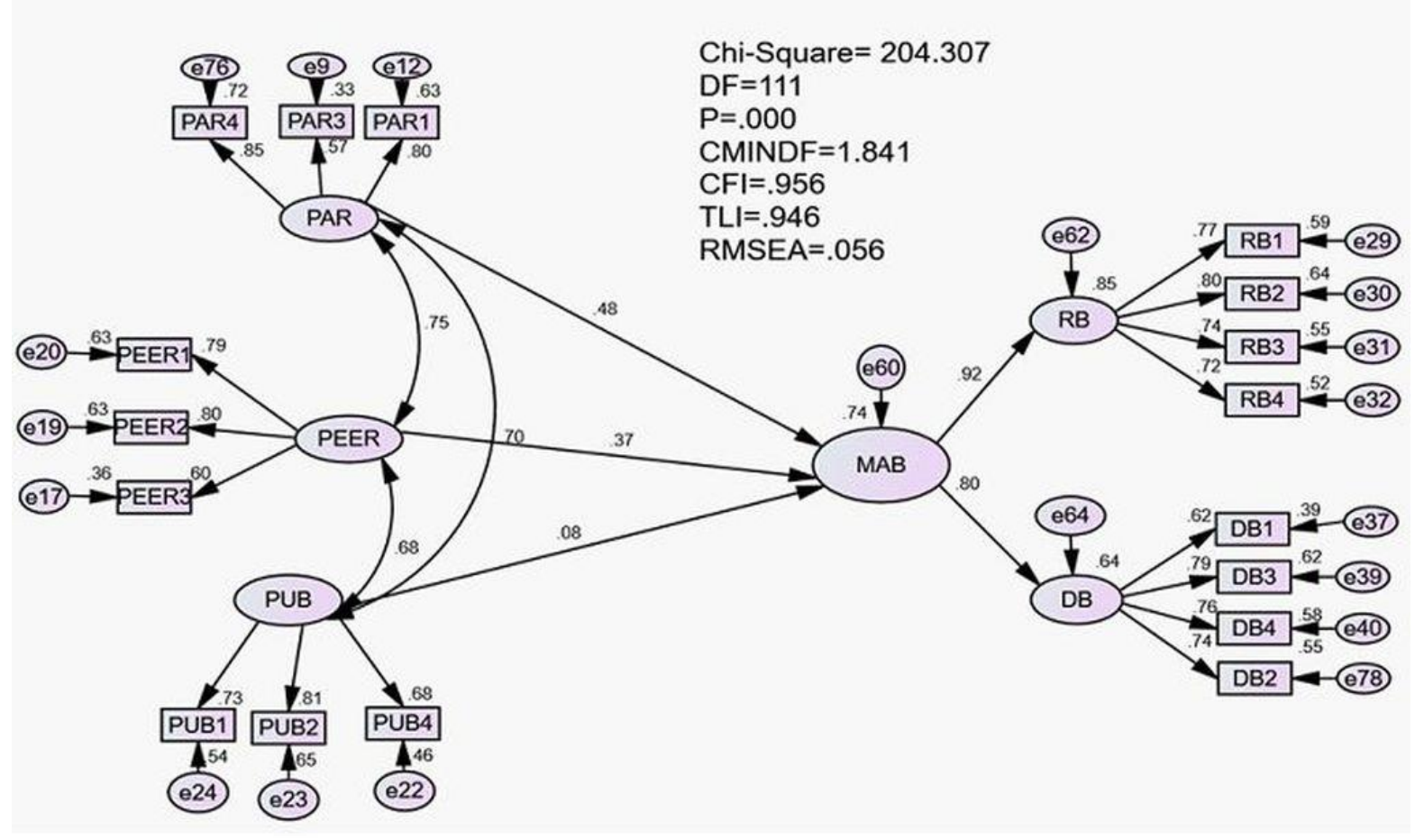

Figure 2. The Study Hypothesized Model 
As shown in Figure 2, the psychological and maladaptive behaviour factors Hypothesized Structural Model showed the hypotheses to be consistent with the data (normed Chi-square $=1.841$; RMSEA $=.056$; CFI $=.956$; TLI $=.946$ ). All these fit indices for the psychological and maladaptive behaviour factors model met the statistical recommended values which indicated a fitting Hypothesized Structural Model.

Additionally, the analysis revealed that the four hypothesized relationships for the three exogenous variables, namely the psychological factor dimensions (parental influence, peer influence and public influence) explained $74 \%$ of the variance of the street working children's maladaptive behavior.

Table 5. Direct hypotheses testing results of structural model

\begin{tabular}{|c|c|c|c|c|c|c|c|}
\hline Нуро & Exog. & $\Longrightarrow$ & Endo. & B & $t$-value & $p$-value & Result \\
\hline $\mathrm{H}_{1}$ & PAR & $\Longrightarrow$ & MAB & .480 & 3.982 & $* * *$ & Supported \\
\hline $\mathrm{H}_{2}$ & PEER & $\Longrightarrow$ & MAB & .368 & 3.217 & .001 & Supported \\
\hline $\mathrm{H}_{3}$ & PUB & & MAB & .083 & .877 & .380 & Not Supported \\
\hline
\end{tabular}

Furthermore, the structural model assessment, as shown in Table 5, provides the indications of the hypotheses test, namely estimates, $\mathrm{t}$-values and p-values. The results indicate that one of the three hypotheses in the model, hypothesized relationship, was statistically not significant. The hypothesized relationship refers to the relationship between the social psychological factor dimensions and public influence $(\beta=.083 ; \mathrm{t}=.877 ; \mathrm{p}>0.05)$. The other two direct hypotheses were statistically significant at $\mathrm{p} \leq 0.01$. These are relationships between the psychological factor dimensions and parents' influence $(\beta=.480 ; \mathrm{t}=3.982 ; \mathrm{p} \leq 0.05)$ and the psychological factor dimensions and peers' influence $(\beta=.368 ; \mathrm{t}=3.217 ; \mathrm{p} \leq 0.05)$.

\section{Discussion}

Parents' education and occupation are crucial background factors that brought the children to the streets. Most of the respondents reported that their parents had no education or proper work which consequently led to severe financial and social deprivation. Moreover, their poor conditions left them with less opportunity to invest in their children's education. Children from poor socio-economic backgrounds would have fewer years in school and poorer quality education and training for good jobs in the future (Baker \& Johnston, 2010). The findings reveal that the street children are obligated to contribute to the family by providing income to them and the children had to be independent and earn for themselves to survive. These findings reveal that the street children are exposed to work at an early age to fend for themselves and their family (Nelson \& Quiton, 2018). Sometimes a child would experience physical, verbal and emotional abuse from parents when he/she returned home without income. It was found that in most cases, the children in this study, either the first or second born, felt the pressure to contribute to the family income and would perform jobs that are dangerous, risky, and illegal.

Peers are considered to have significant influence on street children's behavior as seen in this study. According to Bronfenbrenner's Ecological Theory, children from 10-17 years old are easily affected and influenced by their surrounding environment. The street children spend more time with peers, thus being exposed to peer pressure and peer conformity as stated by Demanet and Van Hautte (2011) and Shahabudin \& Low (2013). The findings of this study reveal the deviant acts that were performed by the street children are usually performed in groups and having colleagues are important for peer support and protection against authorities, the public and other groups of street children.

This study has shown that street children in Khartoum were involved in different types of risk and deviant behaviors, such as smoking cigarettes, drinking alcohol, sniffing glue, sexual activities, physical fighting, begging, stealing and pick-pocketing. Similar to the findings of Saripudin (2012), it was discovered that street children are independent, and they do not abide by the laws. They perform these negative activities as part of their coping strategies to survive the harsh life on the streets. 
The public was not found to have significant influence on the behaviour of street children for this study. This may be because of the lack of trust that the street children felt for the people in public, hence they keep their distance from them to avoid unnecessary problems that could arise by being in close contact with them.

\section{Conclusion}

In conclusion, children who work or live on the streets do not have the full knowledge of their rights and are often unaware of various risks in their unguided urban life. The findings of the current study showed how economic hardship and the street environment have affected the lives of such children and their families. The experience on the street and the environment are the source of information and knowledge that guide their daily lives and future. The government of Sudan and the civil society need to intervene by first looking into creating an intervention program handled by psychologists and counsellors to assist children to overcome problems such as alcohol and drug addiction. In some cases, this support can be provided by children who have already been through and overcome similar problems. Getting someone who went through the process of rehabilitation would be more effective as they could relate well with the street children and could be their source of motivation. The government should provide free education and evaluate and implement short-term and long-term policy plans which include fee waivers and free meals for poor children to encourage attendance to school. Government and NGOs at the upper level and communities and localities at the lower level, should collaborate, provide welfare services and extend charities and donation programs to support low income families. They might provide them with small projects, enterprises, and vocational training to achieve worthy goals to reduce the magnitude of the problem.

\section{Limitations}

Due to the nature of research, the generalisation of the results of the study should be made with caution. Owing to the constraints in carrying out this research only in Khartoum City, Bahri and Omdurman, the researcher did not approach other regions of Sudan (e.g. East and West Sudan) because of security concerns. The researcher selected the areas that are less dangerous for data collection. Future research could extend this research to other regions in Sudan to obtain more conclusive findings on the urban children population about the association among SES, family factors and behavioural and psychological wellbeing. Furthermore, future research could also extend to the rural areas in Sudan to examine if there is a difference between children's behavioural and psychological wellbeing in the urban and rural areas.

Moreover, the nature of a self-reporting investigation has its downside as there is a probability that respondents might under-report or over-report their reactions. In this way, the think-aloud protocol would benefit future studies as the researcher can utilise different sources of witnesses such as parents, guardians and siblings.

Another limitation of this study is the absence of interviews with parents. Future studies should have interviews with the street children's parents as this could provide a clear picture of the street children's personalities, family relationship and daily activities.

\section{Acknowledgements}

The authors declare to have no conflict in this publication. The authors acknowledge the financial support for this study provided by the Population Studies Unit, Faculty of Economics and Administration, Universiti Malaya, towards this study. The university has certainly shown keen interest in studies related to the protection of children and the fight against poverty.

\section{References}

Abdelmoneium, A. O. (2017). Ways to Survive: Child Labor among Internally Displaced Children in Khartoum-Sudan. Open Journal of Social Sciences, 5(9), 53. https://doi.org/10.4236/jss.2017.59004

Abudu, F. (1987). Urban poverty and labor abuse in Benin City. In P. Makinwa, \& O. A. Ozo (Eds.), The urban poor (pp. 323-331). Ibadan. Benin Evans Brothers Publisher.

Alternative CRC Report. (2010). The NGO Report on the Implementation of the International Convention on the Rights of the Child in Sudan. Coordinated by Child Rights Institute, Khartoum.

Ansell, N. (2016). Once upon a time: Orphanhood, childhood studies and the depoliticisation of childhood poverty in Southern Africa. Childhood, 23(2), 162-177. https://doi.org/10.1177/0907568215589419

Apeh, H. A., \& Bernice, E. (2020). Influence of family violence on the maladaptive behaviors of secondary school students in Kogi State, Nigeria. International Journal of Psychology and Counselling, 12(4), 124-130.

Aptekar, L. (1994). Street children in the developing world: A review of their condition. Cross-Cultural Research, 
28(3), 195-224. https://doi.org/10.1177/106939719402800301

Aptekar, L., \& Stoecklin, D. (2014). Street children and homeless youth: A cross-cultural perspective. Dordrecht, Springer. https://doi.org/10.1007/978-94-007-7356-1

Arabi, K. A. M., \& Ali, W. A. (2011). Factors affect homelessness among street children in Khartoum State. Journal of Business Studies Quarterly, 2, 98-106.

Assal, M. A. (2004). Displaced persons in Khartoum: current realities and post-war scenario. Report to the Middle East Awards Program. Cairo: Population Council.

Awad, S. S. (2003). Sudanese street children narrating their life experiences. Journal of Psychology in Africa, 13(2), 133-147.

Azumah, F. D. (2019). Street homes and their security implications in Kumasi Metropolis-Ghana. International Journal Social Science Studies, 7, 83. https://doi.org/10.11114/ijsss.v7i2.4094

Bah, Y. M. (2018). Drug abuse among street children. Journal of Alcohol and Drug Abuse, 2(1), 1004. https://doi.org/10.23916/0020190416610

Baker, M., \& Johnston, P. (2010). The impact of socioeconomic status on high-stakes testing reexamined. Journal of Instructional Psychology, 37(3), 7.

Basnet, P. (2010). The lost childhood of street children in Nepal. Wichita State University.

Beresford, P., Green, D., Lister, R., \& Woodard, K. (1999). Poverty firsthand: Poor people speak for themselves. London: Child Poverty Action Group.

Bibars, I. (1998). Street children in Egypt: from the home to the street to inappropriate corrective institutions. Environment and Urbanization, 10(1), 201-216. https://doi.org/10.1177/095624789801000108

Bordonaro, L. I., \& Payne, R. (2012). Ambiguous agency: critical perspectives on social interventions with children and youth in Africa. Children's Geographies, 10(4), 365-372, https://doi.org/10.1080/14733285.2012.726065

Bronfenbrenner, U. (1986). Ecology of the family as a context for human development: research perspectives. Developmental Psychology, 22(6), 723-742. https://doi.org/10.1037/0012-1649.22.6.723

Bronfenbrenner, U. (1994). Ecological models of human development. In International Encyclopedia of Education (Vol. 3, 2nd ed., pp. 37-43). Oxford: Elsevier.

Bukoye, R. O. (2015). Case study: Prevalence and consequences of streets begging among adults and children in Nigeria, Suleja Metropolis. Procedia-Social and Behavioural Sciences, 171, 323-333. https://doi.org/10.1016/j.sbspro.2015.01.129

Caspi, A., \& Roberts, B. W. (2001). Personality development across the life course: The argument for change and continuity. Psychological Inquiry, 12(2), 49-66. https://doi.org/10.1207/S15327965PLI1202_01

Chamber, S. (1983). Do poor children become poor adults; A conceptual framework in social sciences. London: Elsevier.

Consortium for Street Children. (2004). A civil society forum for north Africa and the middle east on promoting and protecting the right of street children. 3-6 March, Cairo, Egypt: Consortium for Street Children.

Demanet, J., \& Van Houtte, M. (2011). School belonging and school misconduct: the differing role of teacher and peer attachment. Journal of Youth and Adolescence, 41(4), 499-514. https://doi.org/10.1007/s10964-011-9674-2

Eltayeb, G. E. (2001) Human Development Paper presented at the Civil Society Preparatory Conference for the (Rio+10) Summit Conference on Sustainable Development, 2-4 Oct 2001, Khartoum.

Endris, S., \& Sitota, G. (2019). Causes and Consequences of Streetism among Street Children in Harar City, Ethiopia. International Journal of Education and Literacy Studies, 7(2), 94-99. https://doi.org/10.7575/aiac.ijels.v.7n.2p.94

Flowers, R. B. (2001). Runaway kids and teenage prostitution: America's lost, abandoned, and sexually exploited children. Westport, CT: Greenwood Press.

Greksa, L. P., Islam, A. R., Okamoto, R., \& Omori, K. (2017). Dietary patterns and dietary adequacy of street children in Dhaka, Bangladesh. Ecology of Food and Nutrition, 56(6), 479-492. https://doi.org/10.1080/03670244.2017.1381605 
Hamid, G. M. (1994). Population displacement and household coping strategies in Sudan: the view from Greater Khartoum. In S. Shami (Ed.), Population displacement and resettlement: Development and conflict in the Middle-East (pp. 47-79). New York: Center for Migration Studies.

Hassan, S. S., Kobylarczyk, J., Kuśnierz-Krupa, D., Chałupski, A., \& Krupa, M. (2017). Urban planning of Khartoum. History and modernity Part II. Modernity. Wiadomości Konserwatorskie.

Kaiser, E., \& Sinanan, A. N. (2020). Survival and resilience of female street children experiencing sexual violence in Bangladesh: A qualitative study. Journal of Child Sexual Abuse, 29(5), 550-569. https://doi.org/10.1080/10538712.2019.1685615

Kudrati, M., Plummer, M. L., \& Yousif, N. D. E. H. (2008). Children of the Sug: A study of the daily lives of street children in Khartoum, Sudan, with intervention recommendation. Child Abuse and Neglect, 32, 439-448. https://doi.org/10.1016/j.chiabu.2007.07.009

Marrengula, M. L. (2010). Addressing socio-cultural animation as community-based social work with street children in Maputo, Mozambique. Tampere University Press.

Maslow, A. (1954). Motivation and Personality. New York. Harper and Row.

Mayer, S. E. (1997). What money can't buy: Family income and children's life chances. Cambridge, Harvard University Press.

Mella, M. (2012). An investigation into the nature and extent of economic exploitation of street children in Zimbabwe: A case study of Harare Central Business District. Unpublished Master of Social Work dissertation, University of Zimbabwe, Zimbabwe.

NCCW (Sudan's National Council Child Welfare). (2011). Child Act 2010. Khartoum, Sudan.

Nelson, G. L. M., \& Quiton, J. D. (2018). Child labor and its effects on schooling, health and recreation of Filipino children. Journal of Population and Social Studies [JPSS], 26(1), 68-82. https://doi.org/10.25133/JPSSv26n1.006

Nwabah, N. I., \& Uko-aviomoh. (2006). Nigerian street children: Security threat in Edo State. Journal of Family and Consumer Sciences, 98(3).

Okojie, C. E. (1987). Income generation in occupational structure among the urban poor. Owerri Evans Publishers.

Oruwari, Y. (1996). Children and the built environment in Nigeria: Who should they depend on their interests in housing provisions. Port-Harcourt, Hisis Press.

Panter-Brick, C. (2002). Street children, human rights, and public health: A critique and future directions. Annual Review of Anthropology, 31(1), 147-171. https://doi.org/10.1146/annurev.anthro.31.040402.085359

Plummer, M. L., Kudrati, M., \& Yousif, N. D. E. H. (2007). Beginning street life: Factors contributing to children working and living on the streets of Khartoum, Sudan. Children and Youth Services Review, 29(12), 1520-1536. https://doi.org/10.1016/j.childyouth.2007.06.008

Rana, H. U. R., \& Chaudhry, H. U. R. (2011). Street Children: A great loss to human resource development in Pakistan. Pakistan Journal of Social Sciences 31(1). 15-27.

Roshanfekr, P., Vameghi, M., Ali, D., Mahzari, K., Ahounbar, E., \& Noroozi, M. (2020). Lifetime drug use and related factors among street children and youth in Iran in 2016. Journal of Substance Use, 25(5), 519-522. https://doi.org/10.1080/14659891.2020.1738571

Saripudin, D. (2012). The street children develop in an open house. Journal of Social Sciences, 8(2), 267-273. https://doi.org/10.3844/jssp.2012.267.273

Shahabudin, S. M., \& Low, W. Y. (2013). An assessment of the "capital" indicators for measuring the socioeconomic status of high school students and the influence on family and school stressors. Child Indicators Research, 1-20. https://doi.org/10.1007/s12187-013-9192-8

Strachan, A. L. (2016). Rapid fragility and migration assessment for Sudan. (Rapid Literature Review). Birmingham, UK: GSDRC, University of Birmingham.

UNESCO. (2017). Social and human sciences. Retrieved from http://www.unesco.org/new/en/social-and-humansciences/themes/fight-against-discrimination/role-ofeducation/

UNICEF. (2007). The state of the world's children. New York: UNICEF. 
Verma, V., Mishra, A. K., Dhawan, A., \& Nath, D. C. (2020). Diversity in substance use behavior among street children of Delhi under Bayesian paradigm. BMC Medical Research Methodology, 20(1), 1-9. https://doi.org/10.1186/s12874-020-01172-y

Woodward, P. (ed.) (1999). Refugee policy in Sudan 1967-1984 (Vol. 6). Berghahn Books.

Yaqub, S. (2002). 'Poor children grow into poor adults': harmful mechanisms or over-deterministic theory?. Journal of International Development 14(8), 1081-1093. https://doi.org/10.1002/jid.951

\section{Notes}

Note 1. 1a -2 respondents stay with grandparents, 1b-"Other" includes respondents do not have families, 2c- "Other" includes respondents who have been on the street all the time, 3- 1USD = 60 SP (Sudanese's Pound) as of April 2019, 4- only one reported grandparent depended on child's income.

Note 2. 1. Includes one respondent with 22 siblings.

2. a -2 respondents stay with grandparents.

3. b - "Other" includes respondents do not have families.

4. c - "Other" includes respondents who have been on the street all the time

5. d - only one reported grandparent depended on child's income.

6. 1 USD $=60$ SP (Sudanese's Pound) as of April 2019.

7. Type of job "Other" includes petty jobs such as cleaner, conductor, waiter and tea boy.

Note 3. NA is for items with the weight fixed to 1 ; *** denotes p-value $<0.01$

\section{Copyrights}

Copyright for this article is retained by the author(s), with first publication rights granted to the journal.

This is an open-access article distributed under the terms and conditions of the Creative Commons Attribution license (http://creativecommons.org/licenses/by/4.0/). 